Tropical Journal of Pharmaceutical Research December 2011; 10 (6): 755-760

(C) Pharmacotherapy Group, Faculty of Pharmacy, University of Benin

Benin City, 300001 Nigeria.

All rights reserved.

Available online at http://www.tjpr.org

Research Article

http://dx.doi.org/10.4314/tjpr.v10i6.8

\title{
A Protease Isolated from the Latex of Plumeria rubra Linn (Apocynaceae) 2: Anti-inflammatory and Wound- Healing Activities
}

\author{
Indranil Chanda ${ }^{1^{*}}$, Usha Sarma ${ }^{2}$, Sanat K Basu ${ }^{3}$, Mangala Lahkar ${ }^{4}$ and \\ Sadhan K Dutta ${ }^{5}$ \\ ${ }^{1}$ Girijananda Chowdhury Institute of Pharmaceutical Science, Guwahati, Assam-781017, ${ }^{2}$ Department of Pathology, \\ Gauhati Medical College and Hospital, Guwahati, Assam-781032, ${ }^{3}$ Department of Pharmaceutical Technology, \\ Jadavpur University, Kolkata, West Bengal-700032, ${ }^{4}$ Department of Pharmacology, Gauhati Medical College and \\ Hospital, Guwahati, Assam-781032, ${ }^{5}$ A College of Pharmacy, Bengal School of Technology, Hooghly, West Bengal- \\ 712102, India.
}

\begin{abstract}
Purpose: The aim of this study was to investigate the anti-inflammatory and wound-healing activities of the protease isolated from the latex of Plumeria rubra Linn.

Methods: The protease was isolated from the latex of the plant by acetone precipitation method and given a trivial name, Plumerin-R. The anti-inflammatory activity of the protease was based on its effects on carrageenan-induced paw oedema in rats. Its wound healing effect was investigated using an excision wound rat model.

Results: Four hours after treatment, the reduction in carrageenan-induced rat paw oedema by 20, 40 and $80 \mathrm{mg} / \mathrm{kg}$ body weight of plumerin- $R$ was $21.6,33.8$ and $48.8 \%$, respectively, while oedema reduction by indomethacin $(10 \mathrm{mg} / \mathrm{kg})$ was $58.0 \%$. Plumerin- $R$ showed significant $(p<0.05)$ wound closure and epithelialization time compared with control.

Conclusion: This study demonstrates that the protease, Plumerin- $R$, has significant anti-inflammatory and wound-healing properties.
\end{abstract}

Keywords: Protease, Plumerin-R, Anti-inflammatory, Excision wound, Healing. 


\section{INTRODUCTION}

Inflammation is a host defence mechanism in response to various infections, injury or metabolic stimuli. Although it is a defence mechanism, the complex events and mediators involved in inflammatory reaction can induce, maintain or aggravate many diseases [1]. Wound healing is a natural and fundamental histopathological process. Reaction of tissues to injury varies in different species of animals and different tissues. In some cases, the cells lost are replaced by the proliferative activity of those remaining, while in other cases, the healing of the wounds of skin and subcutaneous tissue occurs by the formation of fibrous scars [2].

Plumeria rubra Linn. (Apocynaceae) is a laticiferous tree which grows as a spreading shrub to a height of $7-8 \mathrm{~m}(20-25 \mathrm{ft})$. The species, commonly known as red jasmine, is native to Mexico and grows throughout India [3]. The extensive use of proteolytic enzymes in the treatment of inflammation and wound healing process is a well established fact. Bromelain from Ananas comosu has been shown to possess both anti-inflammatory and wound healing properties [4] while curcain, a protease from Jatropha curcas, was reported to have significant wound healing property [5]. The present study was aimed at investigating the anti-inflammatory and wound healing activities of the protease obtained from Plumeria rubra.

\section{EXPERIMENTAL}

\section{Materials}

The species Plumeria rubra Linn. was collected in the month of April and authenticated by Forest Research Institute, Dehradun, India. A voucher specimen (no. 1917/136250) was deposited in the herbarium of the Forest Research Institute, Dehradun, India for future reference. Latex was collected from the stem of the plant. Carrageenan, polyethylene glycol (PEG) 4000 and PEG 400 were purchased from
Sigma Aldrich India and Merck India while 0.2 $\%$ w/w nitrofurazone ointment was purchased from a pharmacy store in Guwahati, Assam, India.

\section{Preparation of crude enzyme extract}

Latex was collected into glass tubes containing $1 \mathrm{ml}$ of $10 \%$ sodium metabisulphite by incision at the bark of the trunk and branches of the plant. The crude latex was strained through cotton wool to remove suspended coarse inert materials and then centrifuged at $7000 \mathrm{rpm}$ for $30 \mathrm{~min}$. The supernatant was collected and used as the crude enzyme extract. The crude extract was subjected to protein precipitation by adding 3 volumes of chilled acetone slowly to 1 volume of the crude extract and the precipitate formed was separated by centrifugation at $7000 \mathrm{rpm}$ for $30 \mathrm{~min}$. The precipitate was dissolved in minimum volume of water and the protein was re-precipitated by adding chilled acetone. The resulting precipitate was collected by centrifugation (7000 rpm, $30 \mathrm{~min}$ ) and dried at room temperature. All centrifugation steps were performed at $4{ }^{\circ} \mathrm{C}$. Protein estimation [6] and enzyme assay [7] were carried out for the acetone precipitated fraction. Following common practice, the trivial name, "PlumerinR" was given to the protease.

\section{Ointment formulation}

A hydrophilic ointment containing $0.5 \%$ plumerin-R was prepared in polyethylene glycol (PEG) 400 and 4000 ointment base [8].

\section{Animals}

Male Wistar albino rats $(150-175 \mathrm{~g})$ were used for the evaluation of anti-inflammatory and wound-healing activities. They were obtained from the animal house of the institute, were maintained under standard environmental conditions, and fed with standard pellet diet supplied by Hindustan Lever Ltd., Kolkata, India and water ad libitum. The guidelines of the Committee for 
the Purpose of Control and Supervision on Experiments on Animals (CPCSEA), India was followed for handling of the animals during the experiments [9]. The research proposal was approved by the Institutional Animal Ethical Committee, and registered under CPCSEA, India (Reg. No.1372/c/10/ CPCSEA).

\section{Anti-inflammatory activity determination}

The acute anti-inflammatory activity of plumerin- $\mathrm{R}$ was evaluated using carrageenan-induced oedema in rats following the method described by Winter et al [11]. The rat paw oedema was measured with Mercury plethysmometer which had a side capillary tube with graduation mark in millilitre $(\mathrm{ml})$. A mark was made on the right hind paw of rats, just below the tibiotarsal junction so that each time, the paw could be dipped in the mercury column of the plethysmometer up to the mark, to ensure constant paw volume. The observations were made from the capillary tube after dipping the hind paw (up to the mark) of the experimental rats in the mercury column. The paw volume was quantitated by displacement (in $\mathrm{ml}$ ) of mercury by oedema.

The rats were divided into five groups of six rats each. Group I served as control, received normal saline (10 ml/kg, i.p.). Group II served as standard, received indomethacin (i.p.) at dose of $10 \mathrm{mg} / \mathrm{kg}$. Group III, IV and V served as test, received plumerin-R (i.p.) at doses of 20,40 and $80 \mathrm{mg} / \mathrm{kg}$ respectively. After 30 min of treatment, $0.1 \mathrm{ml}$ of $1 \%$ carrageenan solution was injected in the plantar region of the right hind paw of rats. The paw volume was measured at $1,2,3$ and $4 \mathrm{~h}$ after carrageenan injection. The difference between the initial and subsequent reading gave the actual oedema volume. Reduction in paw volume compared to the control animals was considered as anti-inflammatory response.

\section{Assessment of wound healing activity}

The rats were divided randomly into four groups of six rats each and inflicted with excision wounds as described by Morton and Malone [12]. The wound was created on dorsal thoracic region. Before creation of wound, the area was cleaned with soapy water and disinfected with $70 \%$ alcohol. Under anesthesia of $1 \mathrm{ml}$ ketamine hydrochloride (i.p.) at a dose of $50 \mathrm{mg} / \mathrm{kg}$ body weight, a circular excision wound (area: $300 \mathrm{~mm}^{2}$ ) was created using a sterile surgical blade. The entire wound was left open.

The rats in the control group were treated with hydrophilic ointment base while the standard reference group received $0.2 \% \mathrm{w} / \mathrm{w}$ nitrofurazone ointment and the test group 0.5 $\% w / w$ plumerin-R ointment in hydrophilic ointment base. The ointments were topically applied once a day. The parameters evaluated were wound closure and epithelialization time. Wound closure was monitored planimetrically by tracing the wound margin on graph paper on the day the wound was inflicted, and then on the $4^{\text {th }}, 8^{\text {th }}$, $12^{\text {th }}, 16^{\text {th }}$ and $20^{\text {th }}$ day. The period of epithelialization was calculated as the number of days required for falling away of the dead tissue remnants of the wound without any residual raw wound.

\section{Histopathological studies}

Skin tissues were collected from the healed skin of each group of rats and transferred to $10 \%$ neutral buffered formalin (NBF) for $24 \mathrm{~h}$ at $4{ }^{\circ} \mathrm{C}$. The formalin-fixed tissues were dehydrated with alcohol, cleared in xylene and then embedded in paraffin wax (melting point, $\left.58-60^{\circ} \mathrm{C}\right)$. Sections $(5$ to $7 \mu \mathrm{m})$ were deparaffinized, stained with hematoxylin, counterstained with eosin and examined microscopically [13].

\section{Statistical analysis}

The experimental results were expressed as mean \pm SEM. Data were analysed by one- 
way ANOVA using Sigma Plot software (version 10). $P$ values of $<0.05$ were considered as statistically significant.

\section{RESULTS}

\section{Anti-inflammatory activity}

Carrageenan-induced paw oedema was significantly $(p<0.05)$ reduced by both standard and test drugs compared to control (Table 1). The maximum effect of plumerin- $R$ was seen in the dose of $80 \mathrm{mg} / \mathrm{kg}$ and antiinflammatory activity of plumerin- $R$ in this dose was compaeable to standard drug, indomethacin $(10 \mathrm{mg} / \mathrm{kg})$. The reduction in carrageenan induced paw oedema by 20,40 and $80 \mathrm{mg} / \mathrm{kg}$ of plumerin-R after $4 \mathrm{~h}$ were $21.6,33.8$ and $48.8 \%$ respectively, while oedema reduction by indomethacin (10 $\mathrm{mg} / \mathrm{kg}$ ) at the same time was $58.0 \%$.

\section{Wound healing activity}

The studies on excision wound-healing model reveal that significant wound-healing activity was observed in rats treated with $0.5 \%$ plumerin-R ointment (test group) and 0.2 $\% \mathrm{w} / \mathrm{w}$ nitrofurazone ointment (standard group) compared with the control group. There was a reduction in wound area from day 4 onwards in both standard and test drug-treated rats; also on subsequent days, the closure rate was much faster than for control rats (Table 2). The epithelialization time of both standard and test groups was significant compared with control.

\section{Histopathology}

The histopathological results (Figures 1, 2 and 3 ) revealed that on the $16^{\text {th }}$ day, while increased number of fibroblasts can be seen in animals in the control group, the collagen fibres are indistinguishable. Animals treated with $0.2 \% \mathrm{w} / \mathrm{w}$ nitrofurazone ointment (standard group) revealed higher fibrosis and well-formed collagen fibres. On the other hand, animals treated with plumerin- $R$ ointment (test group) showed good collagenization and fibrosis.

\section{DISCUSSION}

Carrageenan-induced inflammation is a useful model to detect anti-inflammatory agents. The development of oedema in the paw of the rat after injection of carrageenan is due to release of histamine, serotonin and prostaglandin-like substances [14]. The significant anti-inflammatory activity of plumerin- $R$ (test drug) and indomethacin (standard drug) observed in the present study may be due to inhibition of the mediators of inflammation such as histamine, serotonin and prostaglandin [15]. This establishes the efficacy of plumerin- $R$ as an efficient therapeutic agent in acute anti-inflammatory conditions.

Table 1: Effect of Plumerin-R on carrageenan-induced rat paw edema (percent swelling in parenthesis)

\begin{tabular}{lllll}
\hline Treatment & \multicolumn{4}{c}{ Mean paw volume $(\mathrm{ml})$} \\
\cline { 2 - 5 } & $1 h$ & $2 h$ & $3 h$ & $4 h$ \\
\hline Control & $0.94 \pm 0.05$ & $1.03 \pm 0.07$ & $1.06 \pm 0.04$ & $1.06 \pm 0.06$ \\
(10ml/kg) & $(23.18 \%)$ & $(41.74 \%)$ & $(61.24 \%)$ & $(69.26 \%)^{* *}$ \\
Indomethacin & $0.33 \pm 0.02^{* *}$ & $0.29 \pm 0.03^{* *}$ & $0.27 \pm 0.02^{* *}$ & $0.25 \pm .04^{*}$ \\
(10mg/kg) & $(13.56 \%)$ & $(21.32 \%)$ & $(27.22 \%)$ & $(29.11 \%)$ \\
Plumerin-R & $0.71 \pm 0.07$ & $0.64 \pm 0.04$ & $0.57 \pm 0.06^{*}$ & $0.56 \pm 0.08^{*}$ \\
(20mg/Kg) & $(20.36 \%)$ & $(37.54 \%)$ & $(48.11 \%)$ & $(54.29 \%)$ \\
Plumerin-R & $0.62 \pm 0.05$ & $0.44 \pm 0.08^{*}$ & $0.42 \pm 0.02$ & $0.39 \pm 0.04^{* *}$ \\
(40 mg/Kg) & $(19.47 \%)$ & $(33.64 \%)$ & $(40.91 \%)$ & $(45.85 \%)$ \\
Plumerin-R & $0.52 \pm 0.04$ & $0.36 \pm 0.04^{* *}$ & $0.33 \pm 0.01)^{* *}$ & $0.31 \pm 0.02{ }^{* *}$ \\
(80 mg/Kg) & $(14.16 \%)$ & $(23.77 \%)$ & $(32.15 \%)$ & $(35.47 \%)$ \\
\hline
\end{tabular}

Note: Values expressed as mean $\pm \operatorname{SEM} ;(\mathrm{n}=6) ;{ }^{*} p<0.05,{ }^{\star \star} p<0.01$ compared to control 


\section{Chanda et al}

Table 2: Effect of Plumerin-R ointment on the excision wound rat model

\begin{tabular}{|c|c|c|c|c|c|c|}
\hline \multirow[t]{2}{*}{ Group } & \multicolumn{5}{|c|}{ Wound closure (\%) } & \multirow{2}{*}{$\begin{array}{r}\text { Epitheliali- } \\
\text { zation (Days) }\end{array}$} \\
\hline & $4^{\text {th }}$ Day & $8^{\text {th }}$ Day & $12^{\text {th }}$ Day & $16^{\text {th }}$ Day & $20^{\text {th }}$ Day & \\
\hline $\begin{array}{l}\text { Control (Ointment } \\
\text { Base) }\end{array}$ & $8.87 \pm 1.02$ & $13.83 \pm 0.90$ & $37.15 \pm 0.92$ & $66.06 \pm 0.76$ & $90.92 \pm 0.44$ & $21.4 \pm 0.8$ \\
\hline $\begin{array}{l}\text { Standard }(0.2 \% \\
\text { w/w nitrofurazone } \\
\text { ointment) }\end{array}$ & $24.13 \pm 0.54$ & $34.83 \pm 0.67$ & $67.10 \pm 0.22^{* \star}$ & $92.01 \pm 0.41^{\star *}$ & 100 & $17.4 \pm 0.03^{\star *}$ \\
\hline $\begin{array}{l}\text { Test }(0.5 \% \\
\text { Plumerin-R } \\
\text { ointment) }\end{array}$ & $7.57 \pm 1.14$ & $17.33 \pm 0.79$ & $50.7 \pm 0.55^{\star}$ & $80.59 \pm 0.38^{\star \star}$ & 100 & $18.3 \pm 0.2^{* *}$ \\
\hline
\end{tabular}

Note: Values expressed as mean \pm SEM; $(n=6) ;{ }^{*} p<0.05,{ }^{\star \star} p<0.01$ compared to control

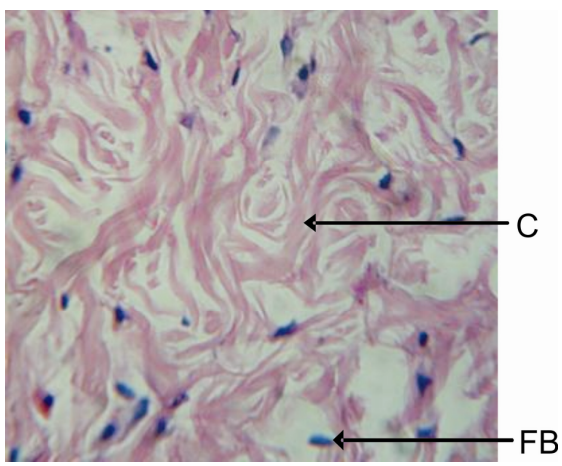

Figure 1: Histopathology of healed tissue $\left(16^{\text {th }}\right.$ day) of control group animals, showing increased number of fibroblasts and indistinguishable collagen fibres $(\mathrm{C}=$ collagen fibre; $\mathrm{FB}=$ fibroblast $)$

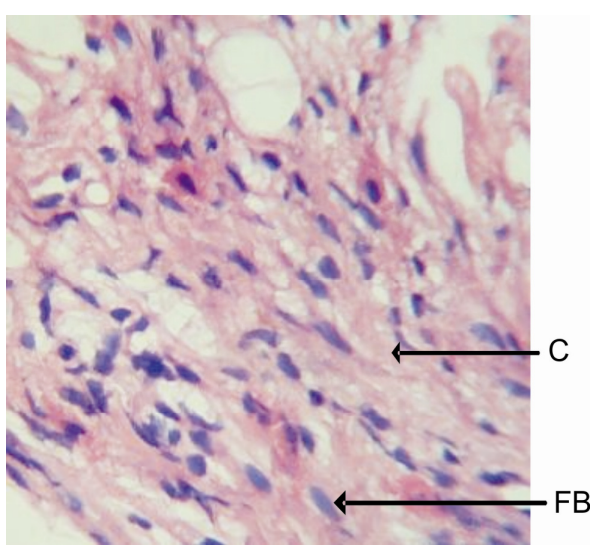

Figure 2: Histopathology of healed tissue $\left(16^{\text {th }}\right.$ day) of standard group animals showing a high level of fibrosis as well as well-formed collagen fibres $(\mathrm{C}=$ collagen fibre; $\mathrm{FB}=$ fibroblast $)$

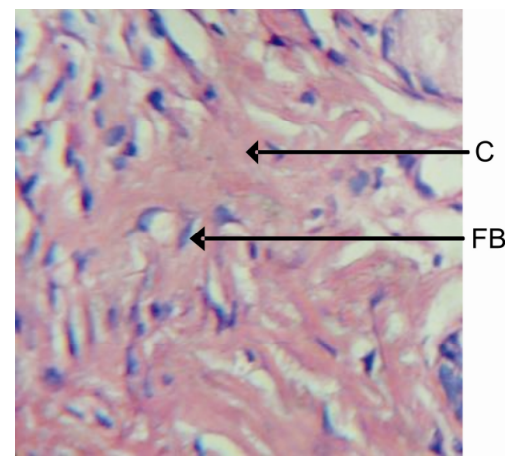

Figure 3: Histopathology of healed tissue $\left(16^{\text {th }}\right.$ day) of test group animals showing fibroblastic proliferation and standard collagenization ( $\mathrm{C}=$ collagen fibre; FB = fibroblast)

Wound-healing or repair is a natural process of regeneration of dermal and epidermal tissue [16]. Wound contracture is a process that occurs throughout the healing process, commencing in the fibroblastic stage whereby the area of the wound undergoes shrinkage [17]. The proliferative phase is characterized by angiogenesis, collagen deposition, granulation tissue formation, epithelialization, and wound contraction resulting in a smaller amount of apparent scar tissue [18]. Following injury, inflammatory response occurs and the cells below the dermis begin to increase collagen production. Later, the epithelial tissue is regenerated. It is well known that stages in healing, namely coagulation, inflammation, fibroblasts formation and collagenization, are intimately interlinked [19]. In the current study, topical 
application of plumerin- $R$ ointment significantly accelerated the rate of wound healing. Histology of healed wound shows comparatively less inflammatory cells and more collagen. Enhanced healing activity has been attributed to collagen formation. Collagen plays a central role in the healing of wounds, is a principal component of connective tissue and provides a structural framework for regenerating tissue [20].

\section{CONCLUSION}

The present study on protease, plumerin-R, from the latex of Plumeria rubra Linn. has demonstrated that it has significant antiinflammatory and wound-healing properties.

\section{ACKNOWLEDGEMENT}

The authors are thankful to the authorities of Girijananda Chowdhury Institute of Pharmaceutical Science, Guwahati, India and S.B.S.P.G. Institute of Biomedical Science \& Research, Dehradun, India for providing facilities to carry out the present research work.

\section{REFERENCES}

1. Kumar V, Abbas AK, Fausto $N$, editors. Robbins and Cotran Pathologic Basis of Disease. Philadelphia: Sevier Saunders; 2004. P 47

2. Ramzi SC, Vinay K, Stanley R. Pathologic Basis of Diseases. Philadelphia: WB Saunders Company; 1994; $P 86$

3. Kritikar KR, Basu BD. Indian Medicinal Plants. Dehradun: International Book Distributors; 2006; $p 1561$

4. Gregory ND. Bromelain: A Literature Review and Discussion of its Therapeutic Applications. Alt Med Rev 1996; 1: 243-257.

5. Nath LK, Dutta SK. Wound healing Response of the Proteolytic Enzyme Curcain. Indian $J$ Pharmacol 1992; 24: 114-115.

6. Lowry OH, Rosenbrough NJ, Farr AL, Randall RJ. Protein measurement with the folin phenol reagent. J Biol Chem 1951; 193: 265-275.
7. Kunitz MI. Crystalline soybean trypsin inhibitor. J Gen Physiol 1947; 30: 291-310.

8. Ugriné HE, Hadi IA, Kassem MA, Farouk AM, Selmeczi B. Formulation of Polyethylene Glycol ointment bases suitable for tropical and subtropical climates. II. Acta Pharm Hung 1989; 59: 157-165.

9. CPCSEA. Guidelines for laboratory animal facility. Indian J Pharmacol. 2003; 35: 257-274.

10. Litchifield JT, Wilcoxan MJ. A simplified method for evaluating dose-effect Experiments. J Pharm Expt Ther 1949; 96: 99-113.

11. Winter CA, Risley EA, Nuss GW. Carrageenaninduced edema in hind paw of the rat as an assay for anti-inflammatory drugs. Proc Soc Exp Biol Med 1962; 111: 544-547.

12. Morton JP, Malone MH. Evaluation of vulnerary activity by open wound procedure in rats. Arch Int Pharmacodyn 1972; 196: 117-120.

13. Mc Manus JGA, Mowry RW. Staining Methods: Histological and Histochemical. New York: Harper and Row; 1984.

14. Vinegar $R$, Schreiber $W$, Hugo R. Biphasic development of carrageenan in rats. $J$ Pharm Expt Ther 1969; 166: 96-103.

15. Singh S, Majumdar DK, Rehan HM. Evaluation of anti-inflammatory potential of fixed oil of Ocimum sanctum (Holybasil) and its possible mechanism of action. J Ethnopharmacol 1996; 54: 19-26.

16. Stadelmann WK, Digenis AG, Tobin GR. Physiology and healing dynamic of chronic cutaneous wounds. Am J Surg 1998; 176: 26- 38.

17. Mirastschijski U, Haaksma CJ, Tomasek JJ, Ågren MS. Matrix metalloproteinase inhibitor GM 6001 attenuates keratinocyte migration, contraction and myofibroblast formation in skin wounds. Experimental Cell Research 2004; 299: 465-475.

18. Midwood KS, Williams LV, Schwarzbauer JE. Tissue repair and the dynamics of the extracellular matrix. Int $J$ Biochem Cell Biol 2004; 36: 1031-1037.

19. Nayak BS, Suresh R, Rao AVC, Pillai GK, Davis EM, Ramkissoon V, McRae A. Evaluation of wound healing activity of Vandarox burghii R.Br (Orchidacea) - A preclinical study in rat model. Int J Low Extrem Wounds 2005; 4: 200-204.

20. Greenhalgh DG. The role of apoptosis in wound healing. Int J Biochem Cell Biol 1998; 30: 1019-1030. 